\title{
The Implementation of Standard 10T in Antenatal Care at Public Health Center of Terminal Banjarmasin
}

\author{
Adriana Palimbo ${ }^{1}$, Dede Mahdiyah ${ }^{1}$, Tuti Alawiyah ${ }^{1}$, Lismawaty $^{2}$ \\ \{adrimkia@yahoo.co.id ${ }^{1}$; tutialawiyah@yahoo.com²; \\ mahdiyahdede@yahoo.co.id ${ }^{3}$; lismaadi14@gmail.com $\left.{ }^{4}\right\}$ \\ ${ }^{1}$ Faculty of Health, Sari Mulia University, Banjarmasin, Indonesia \\ ${ }^{2}$ Graduate, Program of Midwifery Diploma, Sari Mulia University \\ *corresponding author: adrimkia@yahoo.co.id
}

\begin{abstract}
Integrated antenatal coverage in Indonesia has not reached the national target of $90 \%$. The Basic Health Research Report in 2018 recorded $77.6 \%$. The purpose of this study is to describe the implementation of the $10 \mathrm{~T}$ standard service in antenatal care at the Terminal Public Health Center. This research uses a descriptive method, with a sample of 55 pregnant women and 10 midwives. The sample size is determined using a purposive sampling technique. Pregnant women get a low category in the $10 \mathrm{~T}$ standard service of $65.5 \%$. And, the results shown by $80 \%$ midwives are in good category. The results of identification of the characteristics of pregnant women, the category of secondary education are $75 \%$ and as housewives as much as $65.5 \%$ of their total. Overall, many contradictions between the results of midwives and pregnant women in understanding the $10 \mathrm{~T}$ standard. The concern and focus of midwives must be increased in identifying characteristics of pregnant women with low coverage rates so that integrated ANC services are effective and optimal.
\end{abstract}

Keyword: 10 T standard services; pregnant women; midwives

\section{Introduction}

Deaths to women and teenage girls in the world are estimated at 303,000 in 2015, caused by complications of pregnancy and childbirth.[1] These complications cause maternal death around $75 \%$, of the total cases of maternal death, are bleeding, infection, hypertension during pregnancy, childbirth complications, and unsafe abortion. Of the cases of mothers who died most occurred during pregnancy, around $60 \%$ occurred stillbirth or (1.46 million), mainly due to untreated maternal infections, hypertension, and poor fetal growth. Therefore, based on recommendations from the World Health Organization (WHO) in 2018 that the death of women and teenage girls can be prevented if they have access to integrated and quality antenatal care.[2] WHO in the Sustainable Development Goals (SDGs) globally targets MMR of less than 70/100 000 live births by 2030, that all countries must reduce the maternal mortality ratio (MMR) by at least two-thirds of the initial ratio in 2010 for each country. Then, for the national target statement of each country is the Maternal Mortality Ratio (MMR) of no more than 140/100 000 live births. This figure is twice the global target. [3]. 
Furthermore, the MMR in Indonesia according to the 2015 SUPAS is $305 / 100,000$ live births. The study of maternal mortality is a global problem and challenge in the world and Indonesia.[4]. Meanwhile, the Province of South Kalimantan in 2015 saw the number of maternal deaths recorded at 120 mothers. This is the focus of the problem from the low quality of services reflected in the variation and differences in the high maternal mortality rates in some regions, regions and even countries. [5]. Therefore, the government, through the 10T integrated antenatal strategic program, will be able to reduce maternal and infant mortality.

Antenatal Care is a routine health screening service for pregnant women to diagnose obstetric complications as well as to provide information about lifestyle, pregnancy and childbirth.[6] The purpose of the Antenatal Care examination is one of them to prepare women for labor. The readiness of labor is the initial planning and preparation for childbirth that aims to help women, husbands and families to be ready to give birth by making plans to face complications and unexpected things. The routine examination can reduce mortality in pregnant and childbirth women. The service standard is recommended for pregnant women and fetuses in the womb, where the service standard is in the form of early detection of risk factors, prevention and early treatment of pregnancy complications and the achievement of health services for pregnant women, pregnancy service standards are assessed using $\mathrm{K} 1$ and $\mathrm{K} 4$ coverage indicators.[7] Tenaga kesehatan yang kompeten memberikan perawatan prakehamilan dan antenatal yang komprehensif dan berbasis bukti untuk anak perempuan remaja dan wanita. Ini termasuk promosi kesehatan dan informasi tentang perawatan diri, identifikasi dini dan dukungan / manajemen untuk faktor risiko untuk kehilangan / kelahiran janin dan hasil buruk lainnya, dan deteksi dini dan pengobatan atau rujukan komplikasi yang tepat waktu untuk mengoptimalkan kesehatan dan kesejahteraan wanita dan janin selama kehamilan.

Based on the results of a study by Aisyah, et al. (2017) showed that most midwives $(69.7 \%)$ performed the 10T standard in integrated antenatal care properly. [8] Different results are shown from research by Rufaridah, (2019), where $100 \%$ midwives do not implement the 14T standard, but only implement the 7T standard.[9] Achievement of the implementation of the ANC is in line with the results of a study by Hatheral, et al. (2016), which showed communication barriers and the health service system to access the ANC care package.[10] In some countries, studies related to ANC services, service standards, and quality are still low which are also related to access and utilization of the service itself.[11],[12]. Likewise, a study by Thompson, et al. (2013), related to obstacles that affect the implementation of standardized services, suggest four main areas including the presence of antenatal care, frequency of antenatal appointments, location of antenatal care and provision of information. The benefits of access to antenatal care and the needs of pregnant women with clinical risks are inappropriate with a 'one size fits all' approach for others, taking into account their differing psychosocial and educational needs. In some pregnant women, this failure causes disobedient behavior.[13].

Preliminary survey results in Puskesmas Terminal, Banjarmasin Timur District in 2017 obtained data on the number of pregnant women as many as 482 people, in $2016 \mathrm{~K} 1$ were 495 people and $\mathrm{K} 4$ were 461 people. In $2017 \mathrm{~K} 1$ had 576 people and K4 had 568 people and in 2018 K1 had 596 people and K4 had 573 people. Based on the MCH Puskesmas Terminal Report, in $2017 \mathrm{~K} 1$ there were 584 people $(94.8 \%)$ with a target $(97 \%)$. K4 were 566 people $(91.9 \%)$ of the target $(93 \%)$. High risk by health workers as many as 96 people $(77.9 \%)$ with a target $(30 \%)$, high risk by the community as many as 52 people $87.2 \%$. [14] Based on existing theories and phenomena, the purpose of this study is to describe the application of $10 \mathrm{~T}$ standard services in antenatal care at the Puskesmas Terminal. 


\section{Materials and Methods}

This design of research is a quantitative descriptive. The population is all 120 pregnant women in January - February 2019 and 10 midwives who work in the Puskesmas Terminal area. Samples taken by purposive sampling consisted of two subjects, is trimester III pregnant women as many as 55 people and 10 midwives. Data collection uses interviews with questionnaires and a $10 \mathrm{~T}$ service checklist. Univariate data analysis to obtain a description and characteristics of the frequency distribution to describe the $10 \mathrm{~T}$ standard service variables. The univariate analysis in this study describes the implementation of $10 \mathrm{~T}$ standard services in integrated antenatal services presented in the form of frequencies and percentages. To categorize the implementation of $10 \mathrm{~T}$ standard services using the mean value category, which is Good: if $\geq$ mean and Less if $<$ mean.

\section{Results}

\subsection{Characteristics of Respondents}

Respondents consisted of 55 pregnant women and 10 midwives. Characteristics of respondents include age, parity, education, and occupation. Based on the results of the study, obtained the frequency distribution of respondents in table 1 as follows:

Table 1. Frequency Distribution of Respondent Characteristics

\begin{tabular}{|c|c|c|c|c|c|}
\hline \multirow[t]{3}{*}{ No } & \multirow{3}{*}{ Characteristics } & \multicolumn{4}{|c|}{ Respondent } \\
\hline & & \multicolumn{2}{|c|}{ Pregnant Womens } & \multicolumn{2}{|c|}{ Midwives } \\
\hline & & $\mathrm{F}$ & $\%$ & $\mathrm{~F}$ & $\%$ \\
\hline \multirow[t]{3}{*}{1.} & Age (years) & & & & \\
\hline & At risk: $<20 ; \geq 35$ & 33 & 60 & & \\
\hline & Not at risk: $20-34$ & 22 & 40 & & \\
\hline \multirow[t]{3}{*}{2.} & Parity (amount) & & & & \\
\hline & At risk: $=1 ; \geq 5$ & 30 & 54.5 & & \\
\hline & Not at risk: $2-4$ & 25 & 45.4 & & \\
\hline \multirow[t]{6}{*}{3.} & Type of Education & & & & \\
\hline & DIV/S1 (High School) & 6 & 10.9 & 3 & 30.00 \\
\hline & DIII (Diploma)) & 3 & 5.5 & 7 & 70.00 \\
\hline & SMA (Senior High School) & 17 & 30.9 & & \\
\hline & SMP (Junior High School) & 16 & 29.1 & & \\
\hline & SD (Primary School) & 13 & 23.6 & & \\
\hline \multirow[t]{5}{*}{4.} & Type of Work & & & & \\
\hline & Housewife & 36 & 65.5 & & \\
\hline & Entrepreneur) & 13 & 23.6 & & \\
\hline & Teacher / Employee & 6 & 10.9 & 6 & 60.00 \\
\hline & Non employee & 0 & 0 & 4 & 40.00 \\
\hline
\end{tabular}

Based on table 1, it can be seen that from 10 midwives who were distributed based on education, most of the respondents were DIII education with 7 people $(70 \%)$ and others with DIV education of at least 3 people (30\%). From work, as an employee of 6 people $(60 \%)$. For 
55 respondents pregnant women, age and parity were most at risk factors (age $33 ; 60 \%$ and parity $30 ; 54.5 \%)$. Whereas in most senior high school education $17 ; 30.9 \%$ and work status as the housewifes of $36 ; 65.5 \%$.

\subsection{Pregnant Women Receiving Standard Services of 10T}

Table 2. Standard Services of 10T Received by Pregnant Women

\begin{tabular}{cccc}
\hline No & Standard & F & $\%$ \\
\hline 1 & Good & 19 & 34,5 \\
\hline 2 & Less & 36 & 65,5 \\
\hline & Total & 55 & 100 \\
\hline
\end{tabular}

Table 2 shows that out of 55 respondents of pregnant women, the results of the standard services of 10T performed by midwives to pregnant women were good, as many as 36 women $(65,5 \%)$.

\subsection{Midwife Giving Standard Services of 10T}

Table 3. Standard Services of 10T Performed by Midwives

\begin{tabular}{cccc}
\hline No & Standard & F & $\%$ \\
\hline 1 & Good & 8 & 80.00 \\
\hline 2 & Less & 2 & 20.00 \\
\hline & Total & 10 & 100 \\
\hline
\end{tabular}

Table 3 shows that from 10 midwife respondents, it was found that the standard services of $10 \mathrm{~T}$ received by pregnant women from midwives were good 8 midwife $(80 \%)$.

\section{Discussions}

Based on the results of the study of 55 respondents pregnant women, obtained the most perceptions of the implementation of the standard services of $10 \mathrm{~T}$ in the category of Less (65.5\%). Different from the responses obtained from 10 midwife respondents who showed that the implementation of the standard services of $10 \mathrm{~T}$ was mostly done in the Good category $(80 \%)$. In general, differences in respondents' answers between pregnant women and midwives can be related to the characteristics of each individual and the characteristics of the community. The results showed that all respondents in pregnant women with secondary education and below and most jobs in the category of not working or housewives, had a frequency of visits not according to standards, resulting in a lack of information and understanding of the benefits of services received from midwives. Aspects of age and parity are shown in the results of the most categories is age and parity at risk. 
The concept of behavior and health promotion proposed by Notoatmodjo, (2014) [15], that the higher a person's education, the easier it is to receive and provide information and the better the knowledge he possesses so that it affects one's behavior. Likewise in the characteristics of the aspects of age and parity, the more mature a person's age and experience, the more learning and information obtained in relation to the health services received. The concept of McCarthy and Maine, (1992) in Buchan, et al. (2000) [16], recommends by WHO that in addition to being a determinant of causes of maternal death, social determinants are also a strengthening of the service and managerial systems used to approach effective utilization of information and services for maternal health services. Different from the results of previous research researchers, Palimbo, et al. (2019), it is shown in the variables of maternal age and the highest parity in the not risk category and have a significant relation to maternal age $(\mathrm{OR}=0.27 \mathrm{CI} 95 \%=0.09-0.8)$; parity has an OR value of $0.26(95 \% \mathrm{CI}=0.08-0.8)$. It was explained that the age and parity factors were one of the indirect determinants, which could also be related to other factors such as the condition of pregnant women who were unhealthy before pregnancy, quality of service standards and inadequate coverage, and the condition of family and community health status. [17].

This was explained in several previous studies, that a person's characteristics greatly influence health perception, attitude and behavior. A concept by Mubarak, et al. (2007), argues that factors affecting individual understanding can be seen from the level of education and employment, that the higher a person's education, the easier he will receive information. In line with studies by Ainguah, et al. (2018) in Acra, urban areas of Ghana, suggested that demographic aspects including age, education, socioeconomic and individual reproductive status greatly affect women's health status.[18],[19]. Related to the understanding of pregnant women the benefits of getting services according to ANC standards, also stated in the study of Kabudula, et al. (2017) [20], and Diumbuene, et al. (2018) [21], that the condition of the health status and social status of individuals in rural South Africa, revealing different local characteristics can affect the condition of one's health status and social and economic status, as well as by the health system and limited resources in each region.

The results of the study are shown in both categories of midwife respondents, on average midwives perform ANC services according to $10 \mathrm{~T}$ standards. Antenatal care is a program consisting of: health checks, observations, and education for pregnant women in a structured and planned manner to obtain a safe and satisfying pregnancy and childbirth process. Services that cover K1 (first visit) are the first contact of pregnant women with health workers and K4 is contact 4 times or more with health workers who have competence, knowledge, and skills according to standards [7]. Regarding knowledge as an important competency in determining one's attitudes and behavior, according to a study by Syahri (2013), a person without work can obtain information from the surrounding environment that can be obtained through counseling, information counseling and education as well as from print and electronic media so that the community can get information about services. [22] Information received can be obtained through counseling, classes of pregnant women, mentoring of $\mathrm{MCH}$ books, electronic media or prior pregnancy experiences.

The results of the study are shown in the category of less than respondents pregnant women, on average pregnant women still do not understand the knowledge and information about services received at ANC services. This is related to a study by Islam \& Masud, (2018), on the assessment of the level of adherence to pregnancy care, childbirth and childbirth recommended 
by WHO in Bangladesh, that only $31 \%$ of mothers achieved service standards and four or more ANC visits, $37 \%$ of births were performed in health facilities, and $65 \%$ of mothers receive at least one PNC visit. Mothers less than 20 years old, have no education and access to information media, multipara, low economic status, husbands without education and husband's occupational status appear as significant predictors of optimal maternal health care after adjusting for other factors [23]

It was further reviewed that demographic factors were shown in several previous studies, including studies by Hijazi, et al. (2018) in Northern Jordan and review scoping studies by Lattof, et al. (2019), Hijazi argues that the experience of pregnant women about ANC services has a more positive impact leading to increased utilization and quality of service standards in their communities, as long as service providers pay high respect, involve and inform the results of ANC examinations [24]. Meanwhile, Lattof also revealed that the source of data and information is limited about the care system and health resources by the study of Matsubara, et al. (2019) including financing, can influence the adoption of comprehensive measures of quality and quality of the ANC, so it is necessary to raise awareness and better assess the experience of the ANC. [25], [26].

\section{Conclusion}

Antenatal Care is a planned program that includes observation, education, and information on psychological conditions and the physical needs of pregnant women to understand the process of pregnancy and childbirth that is safe and satisfying. Antenatal services are very important for every pregnant woman, regularly checking the condition of the womb during pregnancy will reduce the risk of unwanted labor during the delivery process. Understanding the state of the self and fetal development during pregnancy is important, although at ANC visits most mothers' perceptions are only to know the state of the fetus without understanding what the respondent should know about her pregnancy, or the lack of interest from the respondent to read or find out about the pregnancy. Increased knowledge is not absolutely obtained from formal education but can also be obtained from non-formal education. In addition, support from family, health workers, midwives, and doctors are also a supporting factor for mothers to visit ANC. Thus, the higher the level of mother's education, knowledge and experience of the respondent, the easier it is for mothers to receive health informations. 


\section{References}

[1] WHO: Global Strategy for Women's, Children's and Adolescents' Health (2016-2030). http://apps.who.int/gho/data/node.gswcah. (2017)

[2] WHO, USAID \& MCSP: WHO Recommendations on Antenatal Care for a Positive Pregnancy Experience: Summary. www.mcsprogram.org. (2018a)

[3] WHO: Strategies toward ending preventable maternal mortality (EPMM): Executive Summary. Human Reproductive Programme. (2018b)

[4] Kementerian Kesehatan RI: Profil Kesehatan Indonesia Tahun 2016. Data dan Informasi Kesehatan Profil Kesehatan Indonesia 2016 -smaller size -web. pdf-Diakses Agustus 2017 (2018)

[5] Dinas Kesehatan Propinsi Kalsel: Profil Kesehatan Propinsi Kalsel Tahun 2015. (2016)

[6] Ejigu, T., Woldie, M., \& Kifle, Y: Quality of Antenatal Care Services at Public Health Facilities of Bahir-Dar Special Zone, Northwest Ethiopia. BMC Health Services Research. (2013)

[7] Kementerian Kesehatan RI: Pedoman Pelayanan Antenatal Terpadu, Edisi Kedua. Ditjen Bina GIKIA. (2013)

[8] Aisyah, R.D., Suparni, \& Susiatmi, S.A: Evaluasi Pelaksanaan Standar 10T dalam Pelayanan Antenatal Terpadu. Jurnal Kebidanan. 09 (01) 1 - 101. http: //www. journal.stikeseub.ac.id. (2017)

[9] Rufaridah, A.: Pelaksanaan Antenatal Care (ANC) 14 T pada Bidan di Wilayah Kerja Puskesmas Lubuk Buaya Padang. MENARA Ilmu. 13 (2). E-ISSN 2528-7613. (2019)

[10] Hatherall, B., Morris, J., Jamal, F., \& Sweneey, L., et al.: Timing of the initiation of antenatal care: An exploratory qualitative study of women and service providers in East London. Midwifery. http://dx.doi.org/10.1016/j.midw.2016.02.017. (2016)

[11] Mchenga, M., Burger, R., \& von Fintel, D.: Examining the impact of WHO's Focused Antenatal Care policy on early access, underutilisation and quality of antenatal care services in Malawi: a retrospective study. BMC Health Services Research. 19:295. 2-14. https://doi.org/10.1186/s12913019-4130-1. (2019)

[12] Venkateswaran, M., Bogale, B., Khader, K.A., Awwad, T., \& Friberg,I.K., et al. : Effective coverage of essential antenatal care interventions: A cross-sectional study of public primary healthcare clinics in the West Bank. Plos One. 22 (2). 1-15. (2019)

[13] Thompson, G., Dykes, F., Singh, G., Cawley, L., \& Dey, P: A public health perspective of women's experiences of antenatal care: An exploration of insights from a community consultation. Midwifery. 29. 211-216. (2013)

[14] Puskesmas Terminal. Laporan PWS KIA Wilayah Puskesmas Terminal. Banjarmasin: (2017)

[15] Notoatmodjo, S: Promosi Kesehatan dan Ilmu Perilaku Kesehatan. Jakarta: PT Rineka Cipta. (2014)

[16] Buchan, J. Ball, J. \& O'May, F: Determining skill mix in the health workforce: guidelines for managers and health professionals. http://eresearch.qmu.ac.uk/policies.html. (2000)

[17] Palimbo, A., Salmah, A. U., \& Sari, A. (2019). Determinant Factors of Maternal Mortality from to 2017 A case-control study in Banjar Regency. Indian Journal of Public Health Research \& Development, 10(1), pp. 1188-1192. (2016)

[18] Mubarak, W.1, Chayatin N, Rozikin, Khoirul, \& Supardi: Promosi Kesehatan SebuahPengantar Belajar Mengajar Dalam Pendidikan.yogyakarta:Graha Ilmu (2007)

[19] Ainguah, F., Bailey, C.E., \& Hill, A.G: Women's health status in urban Ghana: dimensions and differentials using short form 36, Health and Quality of Life Outcomes. BMC. 16:74, 2-13. (2018)

[20] Kabudula, C. W., Houla, B., Collinson, M.A., Kahn, K., Gomez-Oliva, F.X., \& Clark, S.J...: Progression of the epidemiological transition in a rural South African setting: Findings from population surveillance in Agincourt 1993-2013, BMC Public Health. 17:424. (2017) 
[21] Diumbuene, Z.T., Amo-Adjei, J., Amugsi, D., Mumah, J., Izugbara, C., \& Beguy, D: Women's Education and Utilization of Maternal Health Services in Africa: A Multi-Country and Socioeconomic Status Analysis. Journal of Biosocial Science, 50(6), 725-748. doi:10.1017/S0021932017000505. (2018)

[22] Syahri: Pengaruh Lingkungan Kerja terhadap Kepuasan Kerja dan Kinerja Karyawan. Malang: Fakultas Ekonomi dan Bisnis Universitas Brawijaya. Diakses 01 Juni 2019 (2013)

[23] Islam, M.M., \& Masud, M.S: Determinants of frequency and contents of antenatal care visits in Bangladesh: Assessing the extent of compliance with the WHO recommendations. Plos One. 13 (9), $2018 \mathrm{https} / / /$ doi.org/10.1371/journal.pone.0204752. (2018)

[24] Hijazi, M.M., \& Masud, M.S: Determinants of antenatal care attendance among women residing in highly disadvantaged communities in northern Jordan: a cross-sectional study. BMC Reproductive Health. 15:106 https://doi.org/10.1186/s12978-018-0542-3. (2018)

[25] Lattof, S.R., Tuncalp, O., Moran, A.C., Bucagu, M., Chou, D., \& Diaz, T., ...: Developing measures for WHO recommendations on antenatal care for a positive pregnancy experience: a conceptual framework and scoping review. BMJ Open. ;9:e024130. doi:10.1136/bmjopen-2018-024130. (2019)

[26] Matsubara, C., Nguyen, T.A \& Murakami, H: Exploring affordability and healthcare-seeking behaviour for delivery and antenatal care among the poor and ethnic minorities in rural Northwestern Viet Nam. Global Health Action. 12. 1556573 https://doi.org/10.1080/ 16549716.2018.1556573. (2019) 